\title{
An Immune Thrombocytopenic Purpura-Like Picture Preceding Chronic Myelomonocytic Leukemia: A Case Series and Review of the Literature
}

\author{
Murat ALBAYRAK ${ }^{1}$, Eylem ELIACIK ${ }^{2}$, Berfu KORUCU ${ }^{3}$, Ayse ISIK ${ }^{2}$, Gursel GUNES ${ }^{2}$, Salih AKSU , \\ Hakan GOKER ${ }^{2}$, Haluk DEMIROGLU ${ }^{2}$, Nilgun SAYINALP' ${ }^{2}$, Ibrahim C. HAZNEDAROGLU ${ }^{2}$, \\ Osman I. OZCEBE ${ }^{2}$, Yahya BUYUKASIK ${ }^{2}$ \\ ${ }^{1}$ Diskapi Training and Research Hospital, Department of Hematology \\ ${ }^{2}$ Hacettepe University Faculty of Medicine, Department of Internal Medicine, Division of Hematology \\ ${ }^{3}$ Hacettepe University Faculty of Medicine, Department of Internal Medicine, Ankara, TURKEY
}

To the editor,

The myelodysplastic syndromes (MDS) are clonal hematopoetic disorders characterized by ineffective hematopoiesis. Autoimmune complications occur, probably more common than thought, in patients with MDS. ${ }^{1-3}$ Autoimmune manifestations are significant causes of morbidity and mortality in MDS and they may be associated with a poor prognosis. ${ }^{2}$

Chronic myelomonocytic leukemia (CMML) is a myelodysplastic and myeloproliferative neoplasm (MDS/ MPD) characterized by cytopenias, persistent monocytosis, morphologic dysplasia and a tendency to transform to acute myeloid leukemia (AML). CMML patients with autoimmunity disorders have been reported as case reports. ${ }^{4}$ There is also an American Society of Hematology (ASH) congress abstract claiming that autoimmunity is more frequent in CMML patients compared to general population. Six out of 20 autoimmunity cases reported in this presentation had ITP. ${ }^{5} \mathrm{Un}$ fortunately, details about these cases were not reported.

Herein we present a case series of 6 patients with CMML preceded by an ITP-like clinical picture in detail. Some of them responded to ITP-related therapies. We think that it is necessary to draw attention to this combination as it bears both diagnostic and therapeutic implications. The cases are summarized in the Table 1.

Autoimmune complications have long been known to occur during the course of MDS. ${ }^{6}$ The pathogenesis of immune dysregulations in MDS partially consists of the involvement of auto-antibodies production by natural
CD5+ autoreactive B-cells, immune tolerance loss, an abnormality in the Fas/Fas ligand mediated signaling pathway, or a persistent antigenic stimulation. However current literature data is not enough for to suggest that autoantibodies play a major role in the pathophysiology of the disease. The prognostic worth of immune abnormalities in MDS is still unclear. ${ }^{7}$

We performed an English literature review on the relationships of MDS and CMML with autoimmunity and ITP. PubMed (http://www.ncbi.nlm.nih.gov/pubmed) and Web of Science (Web of KnowledgeSM [v5.12], Thomson Reuters, http://apps.webofknowledge.com/ WOS) databases were used. CMML and immune thrombocytopenia, CMML and idiopathic thrombocytopenic purpura, CMML and autoimmunity, MDS and immune thrombocytopenia, MDS and idiopathic thrombocytopenic purpura, and MDS and autoimmunity were used as keywords. The literature review was held on December 16, 2013. Although there were a lot of publications on MDS and autoimmunity, we could only find a few congress abstracts on CMML and autoimmunity ${ }^{3,5}$ and 2 case reports on CMML and ITP. ${ }^{4,8}$ Some studies on MDS and autoimmunity also included limited numbers of CMML cases. $^{1,6}$

The relationship between MDS and ITP is two-sided. MDS cases presenting with isolated thrombocytopenia have been described to be confused with ITP. This condition should be suspected especially in elderly ITP cases. ${ }^{9}$ On the other hand an increased incidence of autoimmune disorders including ITP has been described in MDS patients. 
International Journal of Hematology and Oncology $_{\text {gat }}$

\begin{tabular}{|c|c|c|c|c|c|c|}
\hline & Case 1 & Case 2 & Case 3 & Case 4 & Case 5 & Case 6 \\
\hline Initials & $A G$ & ZB & $A G$ & HT & EK & $\mathrm{HY}$ \\
\hline Age & 49 & 63 & 67 & 88 & 68 & 67 \\
\hline Gender & Male & Male & Male & Female & Male & Female \\
\hline Initial complaint & $\begin{array}{l}\text { Petechiae, } \\
\text { ecchymosis, } \\
\text { oral ulcers }\end{array}$ & Nose bleeding & Fatigue & $\begin{array}{l}\text { Peptic ulcer } \\
\text { bleeding }\end{array}$ & Petechiae & Nose bleeding \\
\hline \multicolumn{7}{|l|}{ Initial CBC } \\
\hline WBC, $\times 10^{9} / \mathrm{L}$ & $\mathrm{N}$ & $\mathrm{N}$ & $\mathrm{N}$ & $N$ & $\mathrm{~N}$ & $N$ \\
\hline Hemoglobin, g/dL & $\mathrm{N}$ & $N$ & $\mathrm{~N}$ & $9.6^{\star}$ & N & N \\
\hline Platelet, $\times 10^{9} / \mathrm{L}$ & 18 & 103 & 6 & 76 & 70 & 105 \\
\hline Monocyte, x10\%/L & Unknown & N & 1.2 & 1.3 & Unknown & N \\
\hline $\begin{array}{l}\text { Bone Marrow } \\
\text { at presentation }\end{array}$ & Nondiagnostic & $\begin{array}{l}\text { Hypercellular, mild } \\
\text { dysgranulopoiesis } \\
\text { and megakaryocytic } \\
\text { dysplasia }\end{array}$ & $\begin{array}{l}\text { Increased } \\
\text { megakaryocytes } \\
\text { and M/E }\end{array}$ & $\begin{array}{l}\text { The patient } \\
\text { refused marrow } \\
\text { biopsy }\end{array}$ & Nondiagnostic & $\begin{array}{l}\text { Mildly hypocellular, } \\
\text { normal } \\
\text { megakaryocytic } \\
\text { growth }\end{array}$ \\
\hline $\begin{array}{l}\text { Splenomegaly } \\
\text { at diagnosis }\end{array}$ & Absent & Absent & Absent & Absent & Absent & Absent \\
\hline $\begin{array}{l}\text { Marrow } \\
\text { cytogenetics }\end{array}$ & $\mathrm{N}$ & $\mathrm{N}$ & $\mathrm{N}$ & $\mathrm{N}$ & $\mathrm{N}$ & $N$ \\
\hline Initial diagnosis & ITP & $\begin{array}{l}\text { Idiopathic } \\
\text { thrombocytopenia }\end{array}$ & ITP & ITP & ITP & $\begin{array}{l}\text { Idiopathic } \\
\text { thrombocytopenia }\end{array}$ \\
\hline Date of initial diagnosis & 1999 & 2010 & 2003 & 2005 & 2010 & 2007 \\
\hline Initial therapies & $\begin{array}{l}\text { High dose CS } \\
\text { and IVIG }\end{array}$ & $\begin{array}{l}\text { Follow-up } \\
\text { without drug }\end{array}$ & $\begin{array}{l}\text { High dose CS } \\
\text { and IVIG }\end{array}$ & $\begin{array}{l}\text { Follow-up } \\
\text { without drugs }\end{array}$ & $\begin{array}{l}\text { Follow-up } \\
\text { without drugs }\end{array}$ & CS and IVIG \\
\hline Response to CS & No response & & No response & & & No response \\
\hline Response to IVIG & No response & & $100 \times 10 \% / L$ & & & No response \\
\hline Splenectomy (date) & Yes (1999) & Yes (2013) & Yes (2013) & No & No & No \\
\hline $\begin{array}{l}\text { Response to } \\
\text { splenectomy }\end{array}$ & $\begin{array}{l}\text { Partial response } \\
\left(40 \times 10^{9} / L\right)\end{array}$ & $\begin{array}{l}\text { Complete } \\
\text { response }\end{array}$ & $\begin{array}{l}\text { Complete } \\
\text { response }\end{array}$ & & & \\
\hline $\begin{array}{l}\text { Date of CMML diagnosis } \\
\text { (interval from initial } \\
\text { presentation) } \\
\text { CBC at CMML diagnosi }\end{array}$ & 2012 (13 years) & 2013 (3 years) & 2005 (2 years) & 2013 (8 years) & 2013 (3 years) & 2013 (6 years) \\
\hline WBC, $\times 10 \% / L$ & 179 & 17.7 & 48 & 96 & 10 & 135 \\
\hline Hemoglobin, g/dL & 10.5 & 8.1 & 12.9 & 12 & 7 & 10.4 \\
\hline Platelet, $\times 10^{9} / \mathrm{L}$ & 14 & 32 & 141 & 129 & 11 & 77 \\
\hline Monocyte, x109/L & 3.8 & 1.6 & 20.6 & 2.7 & 1.2 & 27 \\
\hline $\begin{array}{l}\text { Bone marrow at } \\
\mathrm{CMML} \text { diagnosis }\end{array}$ & $\begin{array}{l}\text { Blast } 10 \% \text {, } \\
\text { increased mono- } \\
\text { cyte precursors } \\
\text { and } \mathrm{M} / \mathrm{E}\end{array}$ & $\begin{array}{l}\text { Hypercellular, } \\
\text { increased monocyte } \\
\text { precursors and } \\
\text { trilineage dysplasia }\end{array}$ & $\begin{array}{l}\text { Hypercellular, } \\
\text { increased M/E, } \\
\text { increased } \\
\text { megakaryocytes }\end{array}$ & $\begin{array}{l}\text { Hypercellular, } \\
\text { increased monocyt } \\
\text { precursors and } \\
M / E\end{array}$ & $\begin{array}{l}\text { Hypercellular, } \\
\text { e increased } \mathrm{M} / \mathrm{E} \text {, } \\
\text { myeloid and } \\
\text { erythroid dysplasia }\end{array}$ & $\begin{array}{l}\text { Hypercellular, } \\
\text { increased M/E, } \\
\text { compatible with } \\
\text { MDS/MPD }\end{array}$ \\
\hline CMML Score & Intermediate-2 & Intermediate-2 & Intermediate-2 & Intermediate-1 & Intermediate-2 & Intermediate-2 \\
\hline $\begin{array}{l}\text { Treatment after } \\
\text { CMML diagnosis }\end{array}$ & $\begin{array}{l}\text { Hydroxyurea } \\
\text { 5-azacitidine } \\
\text { ASCT }\end{array}$ & Splenectomy & Hydroxyurea & Hydroxyurea & IVIG & $\begin{array}{l}\text { Hydroxyurea } \\
\text { Leukapheresis }\end{array}$ \\
\hline $\begin{array}{l}\text { Response to } \\
\text { treatment of CMML }\end{array}$ & $\begin{array}{l}\text { Partial improve- } \\
\text { ments in blood } \\
\text { cell counts after } \\
\text { hydroxyurea and } \\
\text { 5-azacytidine. } \\
\text { Complete res- } \\
\text { ponse after ASCT }\end{array}$ & $\begin{array}{l}\text { WBC: } 75.1 \\
\text { Hemoglobin: } 9.9 \mathrm{~g} / \mathrm{dL} \\
\text { Platelet: } 200 \\
\text { (Follow-up } \\
\text { countinues with } \\
\text { hydroxyurea after } \\
\text { - splenectomy) }\end{array}$ & $\begin{array}{l}\text { WBC normalized } \\
\text { with hydroxyurea } \\
\text { Transformation } \\
\text { to AML and } \\
\text { death in } 2006 .\end{array}$ & $\begin{array}{l}\text { WBC: } 21.8 \\
\text { Hemoglobin: } 8.6 \\
\text { Platelet: } 67 \\
\text { (Lost to follow-up } \\
\text { since April 2013) }\end{array}$ & $\begin{array}{l}\text { No response } \\
\text { (Died due to } \\
\text { COPD in 2013) }\end{array}$ & $\begin{array}{l}\text { No response } \\
\text { (Died due to } \\
\text { leukostasis } \\
\text { in 2013) }\end{array}$ \\
\hline
\end{tabular}


In one of the studies on autoimmunity in MDS, autoimmune diseases were found in 20 of 248 (7\%) cases. Biopsy-confirmed skin vasculitis was diagnosed in 5 patients and rheumatoid arthritis was diagnosed in 4 patients. Autoimmune hemolytic anemia, Sweet's syndrome and Sjögren's sicca syndrome were diagnosed in 2 patients each and myasthenia gravis, temporal arteritis, pyoderma gangrenosum (PG), livedo reticularis with Raynoud syndrome and necrotizing panniculitis were diagnosed in 1 patient each. ${ }^{7}$ There were $12(4.2 \%)$ additional patients with asymptomatic serologic immunological abnormalities. In a study including 221 MDS patients, Enright et al. ${ }^{2}$ found that $30(13.6 \%)$ cases had associated autoimmune disorders. In a large study published in abstract form, the rate of autoimmunity between 1408 MDS cases who had been followed for a median of 74 months was found to be $28 \%{ }^{3}$ The autoimmune diseases were as follows: hypothyroidism $(\mathrm{n}=171,44 \%)$, ITP $(\mathrm{n}=$ $46,12 \%)$, rheumatoid arthritis $(n=41,10 \%)$, gout $(\mathrm{n}=36,9 \%)$, psoriasis $(\mathrm{n}=28,7 \%)$ and other autoimmune diseases with $<5 \%$ prevalence. In this study, median OS was longer in patients with autoimmune diseases compared to other cases. No difference was found in terms of response to treatment, including lenalidomide or azacitidine, between the two groups. ${ }^{3}$ In another study, 82 MDS cases were analyzed retrospectively and autoimmune diseases were identified in 10 cases $(12 \%) \cdot{ }^{10}$ ITP was observed in only one of the cases. Significant difference was not found in MDS patients with and without autoimmune diseases in terms of survival. In a compilation of Voulgarelis et al. ${ }^{11}$ the possibility of autoimmune disase in MDS was reported to be near $10 \%$.

CMML was considered to be a subtype of MDS in the historical French-American-British (FAB) MDS classification system. Currently, this disorder is accepted as a MDS/MPD neoplasm. We have previously reported an atypical case of MDS/MPD with secondary PG who was treated successfully with thalidomide and interferon-alpha2a combination therapy. ${ }^{4,12}$ CMML was suggested to be related to autoimmunity shortly after the description of the FAB MDS classification. ${ }^{6}$ The association between CMML and autoimmune disease may be related due to a defective monocyte/macrophage function, causing to persistent stimulation of immune system as a result of poor bacterial clearance. ${ }^{4}$ In a study related to autoimmunity in MDS and CMML, Saif et al. ${ }^{1}$ reported 3 cases of CMML with autoimmune disorders, namely PG, vasculitis, and ITP. PG was reported to improve with cyclophosphamide, etoposide, prednisone chemotherapy. On the other hand, the ITP case was responsive to prednisone. A recent ASH congress presentation investigated the association between CMML and autoimmunity. ${ }^{5}$ In this study, the presence of autoimmune disorders was significantly higher in CMML compared to historical data on the general population (5-8\%) and Moffitt Cancer Center patients with chronic myeloid leukemia (CML). 123 patients who were diagnosed with CMML between the years 1999 and 2011 were evaluated retrospectively and 20 cases (16.26\%) (8 female and 12 male) were determined to have autoimmune diseases. These cases were rheumatoid arthritis $(n=3,2.4 \%)$, multiple sclerosis $(n=2$, $1.6 \%)$, Sjogren's syndrome $(\mathrm{n}=1,0.8 \%)$, inflammatory bowel disease $(\mathrm{n}=1,0.8 \%)$, autoimmune anemia $(\mathrm{n}=1,0.8 \%)$, psoriasis $(\mathrm{n}=4,3.25 \%)$, polymyalgia rheumatica $(n=1,0.8 \%)$, ITP $(n=6,4.9 \%)$, and hyperthyroidism $(n=2,1.6 \%)$. In 3 cases, multiple autoimmune diseases were found. In this study, only 6 out of $116 \mathrm{CML}$ patients were detected to have autoimmune diseases. This frequency was similar with the general population. ${ }^{5}$

The gender distribution of our cases was 4 men and 2 women. All of them presented with isolated thrombocytopenia of various degrees, ranging from 6 to $10^{5} \times 10^{9} / \mathrm{L}$. The case 4 had associated anemia on presentation. However, this was related to gastrointestinal hemorrhage and improved during follow-up. Initially, marrow cytogenetic examination was normal in all patients. Splenomegaly was not observed in any patient. Mild monocytosis (1.2 and $1.3 \times 10^{9} / \mathrm{L}$ ) was present in 2 cases (cases 3 and 4) at initial presentation. This data was absent in 2 cases and 2 patients (cases 2 and 6) had normal monocyte counts. Although marrow dysplasia was observed in case 2 at diagnosis, this finding was considered to be mild and incompatible with MDS. The initial diagnosis was ITP in 4 patients and idiopathic thrombocytopenia in 2 patients (cases 2 and 6).

Three patients were initially followed up without medications. The other 3 received corticosteroid and IVIG treatments. No responses were observed to corticosteroid treatment. However, one out of 3 cases (case 3) responded to IVIG with an increase of platelet count from 6 to $100 \times 10^{9} / \mathrm{L}$. Splenectomy was performed in 3 patients, shortly after the diagnosis of ITP (without splenomegaly) in 2 of them (cases 1 and 3) 
and after establishment of CMML picture including splenomegaly in one case (case 2). Two complete responses (cases 2 and 3) and one partial response (case 1) were observed.

Limited data related to splenectomy in CMML have been published in the literature. In a Mayo Clinic study, 4 of 11 CMML patients (36\%) with thrombocytopenia showed improvement of thrombocytopenia after splenectomy. Three of the 4 responders had splenic histology resembling immune thrombocytopenia, an abundance of CD68 (PGM1)-positive foamy histiocytes in the marginal zone surrounding the splenic white pulpa. Interestingly, two of these three patients had thrombocytopenia out of proportion to the degree of anemia pre-operatively, suggestive of peripheral destruction of platelets. ${ }^{13}$ The authors concluded that their data suggest peripheral destruction of platelets as a mechanism contributing to thrombocytopenia in a subset of CMML patients. Splenic specimen was available in only one of our cases (case 2). We could not observe above-mentioned finding in this case who attained complete remission after splenectomy.

In conclusion, this case series and some previous reports ${ }^{1,4,5,8,13}$ suggest that the association of CMML and immune platelet destruction, including an ITP-like picture at presentation as we described here, may be a disease-specific condition instead of a rare coincidence. We think that it is necessary to draw attention to this combination as it bears both diagnostic and therapeutic implications.

\section{REFERENCES}

1. Saif MW, Hopkins JL, Gore SD. Autoimmune phenomena in patients with myelodysplastic syndromes and chronic myelomonocytic leukemia. Leuk Lymphoma 43: 2083-2092, 2002.

2. Enright $H$, Jacob HS, Vercellotti $G$, et al. Paraneoplastic autoimmune phenomena in patients with myelodysplastic syndromes: response to immunosuppressive therapy. $\mathrm{Br} \mathrm{J}$ Haematol 91: 403-408, 1995.

3. Komrokji RS, Kulasekararaj AG, Al Ali NH, et al. Characteristics and outcome of myelodysplastic syndromes (MDS) patients with autoimmune disease. 55th ASH Annual Meeting and Exposition. New Orleans, LA. Oral Poster Abstract. Poster No: 746. December 7-10, 2013.

4. Mainwaring CJ, Shutt J, James CM. Not all cases of idiopathic thrombocytopenic purpura [correction of pupura] are what they might first seem. Clin Lab Haematol 24: 261-262, 2002.
5. Peker D, Padron E, Horna P, et al. A close association of history of autoimmunity with chronic myelomonocytic leukemia (CMML) in contrast to chronic myelogeneus leukemia (CML). 54th ASH Annual Meeting and Exposition. Atlanta, GA. Oral and Poster Abstract. Poster No: 1712. December 8-11, 2012.

6. Mufti GJ, Figes A, Hamblin TJ, et al. Immunological abnormalities in myelodysplastic syndromes. I. Serum immunoglobulins and autoantibodies. Br J Haematol 63: 143-147, 1986.

7. Marisavljevic D, Kraguljac N, Rolovic Z. Immunologic abnormalities in myelodysplastic syndromes: clinical features and characteristics of the lymphoid population. Med Oncol 23: 385-391, 2006.

8. Ural AU, Kaptan K, Avcu F, et al. Chronic myelomonocytic leukemia developed 2 years after the onset of immune thrombocytopenic purpura like syndrome. Haematologia (Budap) 30: 221-224, 2000.

9. Bizzoni L, Mazzucconi MG, Gentile M, et al. Idiopathic thrombocytopenic purpura (ITP) in the elderly: clinical course in 178 patients. Eur J Haematol 76: 210-216, 2006.

10. Billström $\mathrm{R}$, Johansson $\mathrm{H}$, Johansson $\mathrm{B}$, et al. Immunemediated complications in patients with myelodysplastic syndromes--clinical and cytogenetic features. Eur J Haematol 55: 42-48, 1995.

11. Voulgarelis M, Giannouli S, Ritis K, et al. Myelodysplasiaassociated autoimmunity: clinical and pathophysiologic concepts. Eur J Clin Invest 34: 690-700, 2004.

12. Koca E, Duman AE, Cetiner D, et al. Successful treatment of myelodysplastic syndrome-induced pyoderma gangrenosum. Neth J Med 64: 422-424, 2006.

13. Steensma DP, Tefferi A, Li CY. Splenic histopathological patterns in chronic myelomonocytic leukemia with clinical correlations: reinforcement of the heterogeneity of the syndrome. Leuk Res 27: 775-782, 2003.

\section{Correspondence}

Dr. Murat ALBAYRAK

Dışkapı Yıldırım Beyazıt Eğitim ve

Araştırma Hastanesi, Hematoloji Kliniği

Dışkapı, ANKARA / TURKEY

Tel: (+90.312) 5962323

Fax: (+90.312) 3186690

E-mail: muratalbayrak71@yahoo.com 